Prepared in cooperation with The Nature Conservancy

\title{
Freshwater Mussel Survey for the Columbia Dam Removal, Paulins Kill, New Jersey
}

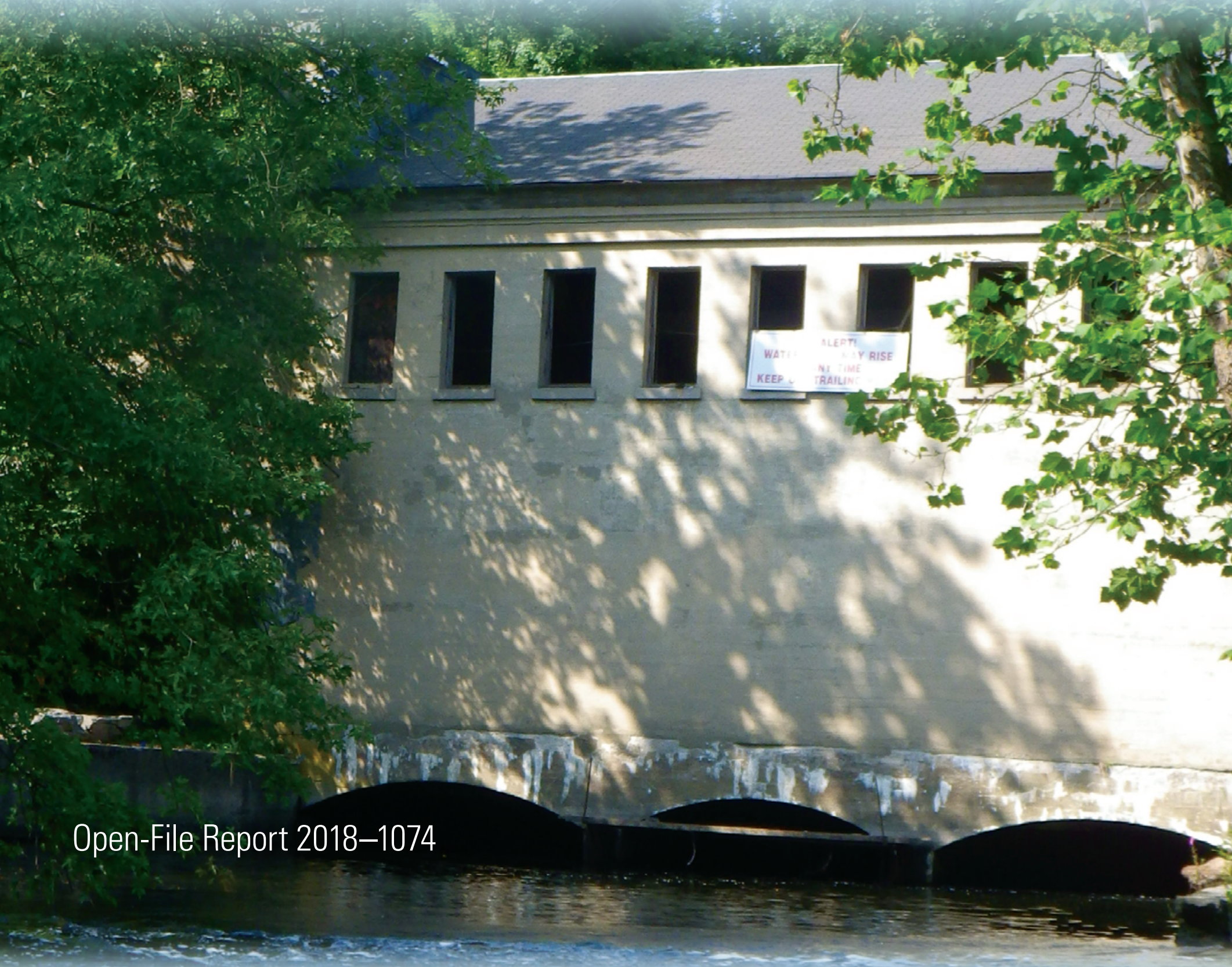

U.S. Department of the Interior U.S. Geological Survey 
Cover. Composite image. Photograph of the Columbia Dam pumphouse and Columbia Dam by Jeff Cole, U.S. Geological Survey on August 22, 2017. Photograph of mussels by Peter Secan, Unsplash on January 11, 2018. 


\section{Freshwater Mussel Survey for the Columbia Dam Removal, Paulins Kill, New Jersey}

By Heather S. Galbraith, Carrie J. Blakeslee, Jeffrey C. Cole, and Erik L. Silldorff

Prepared in cooperation with The Nature Conservancy

Open-File Report 2018-1074 


\title{
U.S. Department of the Interior \\ RYAN K. ZINKE, Secretary
}

\section{U.S. Geological Survey James F. Reilly II, Director}

\author{
U.S. Geological Survey, Reston, Virginia: 2018
}

For more information on the USGS - the Federal source for science about the Earth, its natural and living resources, natural hazards, and the environment—visit https://www.usgs.gov or call 1-888-ASK-USGS.

For an overview of USGS information products, including maps, imagery, and publications, visit https://store.usgs.gov.

Any use of trade, firm, or product names is for descriptive purposes only and does not imply endorsement by the U.S. Government.

Although this information product, for the most part, is in the public domain, it also may contain copyrighted materials as noted in the text. Permission to reproduce copyrighted items must be secured from the copyright owner.

Suggested citation:

Galbraith, H.S., Blakeslee, C.J., Cole, J.C., and Silldorff, E.L., 2018, Freshwater mussel survey for the Columbia Dam removal, Paulins Kill, New Jersey: U.S. Geological Survey Open-File Report 2018-1074, 7 p., https://doi.org/10.3133/ ofr20181074.

ISSN 2331-1258 (online) 


\section{Acknowledgments}

The authors thank Kristin Boggs and Hannah Collins of the U.S. Geological Survey (USGS)

for their assistance in the field; Jeanette Bowers (New Jersey Department of Environmental

Conservation), David Smith (USGS), and Joseph Snavely (Normandeau Associates, Inc.) for input

on survey design; and Richard Evans (National Park Service) and Richard Spear (Pennsylvania

Department of Environmental Protection) for comments that greatly improved the report. 


\section{Contents}

Acknowledgments .........................................................................................................................ii

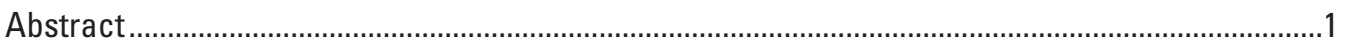

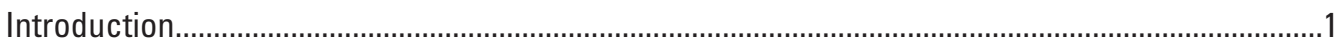

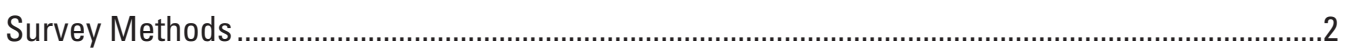

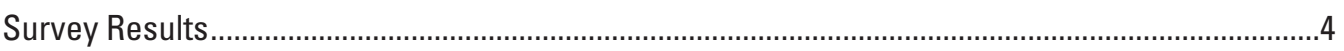

Conclusions and Limitations ...................................................................................................

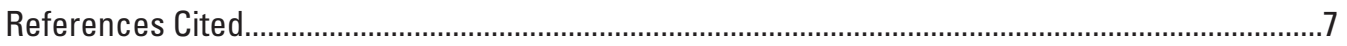

\section{Figures}

1. Map showing survey sections upriver and downriver from the Columbia Dam in the Paulins Kill, New Jersey...

2. Graphs showing results of semi-quantitative freshwater mussel surveys in the Paulins Kill, upriver and downriver from the Columbia Dam, New Jersey, August 2017, for $A$, average and total mussel species richness, $B$, total mussel CPUE (catch per unit effort), and $C$, mussel species richness and total mussel CPUE within 16 individual survey sections

3. Graph showing average (standard error) habitat scores for nine parameters from assessments conducted in the Paulins Kill, New Jersey, upriver and downriver from the Columbia Dam, August 2017.

\section{Tables}

1. Summary of semi-quantitative snorkel and SCUBA surveys for seven freshwater mussel species upriver and downriver from the Columbia Dam, Paulins Kill, New Jersey, August 2017.

2. Summary of freshwater mussel semi-quantitative snorkel and SCUBA surveys of eight mussel species completed upriver and downriver from the Columbia Dam, on Paulins Kill, New Jersey, August 2017, and upstream from Brugler Road within Paulins Kill, July 2007. 


\section{Conversion Factors}

U.S. customary units to International System of Units

\begin{tabular}{lcl}
\hline \multicolumn{1}{c}{ Multiply } & By & \multicolumn{1}{c}{ To obtain } \\
\hline meter $(\mathrm{m})$ & Length & foot $(\mathrm{ft})$ \\
kilometer $(\mathrm{km})$ & 3.281 & mile $(\mathrm{mi})$ \\
\hline & 0.6214 & \\
\hline square meter $(\mathrm{m} 2)$ & Area & square foot (ft2) \\
square kilometer $(\mathrm{km} 2)$ & 10.76 & square mile (mi2) \\
\hline
\end{tabular}

\section{Datum}

Horizontal coordinate information is referenced to the North American Datum of 1983 (NAD 83).

\section{Abbreviations}

CPUE Catch per unit effort

TNC The Nature Conservancy

USGS U.S. Geological Survey 



\title{
Freshwater Mussel Survey for the Columbia Dam Removal, Paulins Kill, New Jersey
}

\author{
By Heather S. Galbraith', Carrie J. Blakeslee', Jeffrey C. Cole', and Erik L. Silldorff ${ }^{2}$
}

\section{Abstract}

Semi-quantitative mussel surveys, conducted by the U.S. Geological Survey and the Delaware Riverkeeper Network in cooperation with The Nature Conservancy, were completed in the vicinity of the Columbia Dam, on the Paulins Kill, New Jersey, in August 2017 in order to document the mussel species composition and relative abundance prior to removal of the dam. Surveys were conducted from the Brugler Road Bridge downriver approximately 2,000 meters $(\mathrm{m})$ to the Columbia Dam and downriver from the dam about $300 \mathrm{~m}$ to $75 \mathrm{~m}$ upriver from the confluence of the Paulins Kill with the Delaware River. Sixteen sections (average length $=175 \mathrm{~m}$ ) were surveyed by personnel snorkeling or SCUBA diving; 13 sections were upriver from the dam, and 3 were downriver from the dam. Mussels, as they were encountered by surveyors, were removed from the sediment, immediately identified to species, and replaced in their original collection locations. Habitat data were collected for each surveyed section. Upriver and downriver from the dam, river margins with dense vegetation were examined for mussels by personnel using snorkels in transects (approximately 25 meters) perpendicular to river flow every $50 \mathrm{~m}$ on both sides of the river. Only two species were found upriver from the dam, and those were present in relatively low numbers. Catch per unit effort is reported here within parentheses as the average across upriver sections in number of mussels per person hour of survey time: 42 Elliptio complanata (2.6) and 1 Pyganodon cataracta (0.1) were found upriver from the dam. No mussels were found in the dense vegetation either upriver or downriver of the dam by surveyors using snorkels. Significantly higher species richness and mussel catch per unit effort were found downriver from the dam than upriver, including 106 E. complanta (32.5), 27 Utterbackiana implicata (8.2), 1 Alasmidonta undulata (0.4), 2 Lampsilis cariosa (0.5), 6 Lampsilis radiata (2.1), 4 P. cataracta (1.1), and 1 Strophitus undulatus (0.4). The average habitat assessment score did not differ upriver and downriver from the dam.

${ }^{1}$ U.S. Geological Survey.

${ }^{2}$ Delaware Riverkeeper Network.

\section{Introduction}

The world's rivers have been vastly altered by reservoir construction and management (Poff and others, 2007). Although dams provide a number of important goods and services to humans including water for drinking, irrigation, industry, and recreation, they can have detrimental effects on native aquatic and riparian species. Dams have been shown to alter the physical (sediment, geomorphology, flow), chemical (nutrients), and biological (connectivity, diversity, trophic dynamics) characteristics of streams and rivers (Baxter, 1977). Dam removal for river restoration has gained increased support, creating numerous opportunities to further scientific understanding of the effects of removal on aquatic ecosystems (Bednarek, 2001; Hart and others, 2002). Although the effects of dam removal have been well documented for some species, other species have not been well studied, such as freshwater mussels.

Mussels are a highly imperiled group of organisms that perform important services in the streams and rivers they inhabit (Strayer and others, 2004; Vaughn, 2010). Mussels are particularly susceptible to anthropogenic disturbances because of their limited mobility (they cannot move to escape stressful events), their complex life history that relies on a host fish for successful reproduction, and their longevity and therefore their long time span to recolonize following disturbance (Haag, 2012). Few studies have addressed the response of freshwater mussels to dam removal and documented post-removal recolonization. Sethi and others (2004) suggest that mussels can be negatively affected (1) upstream from dams owing to stranding and desiccation as water levels drop and (2) downstream from dams owing to suffocation by released sediment plumes. Preremoval planning for dam removal (for example, deploying mussel salvage teams) may ameliorate some of these effects.

The Paulins Kill in New Jersey is a tributary (drainage area, about 460 square kilometers $\left[\mathrm{km}^{2}\right]$ ) to the Delaware River and is impounded in its most downstream location by the Columbia Dam (fig. 1) about 450 meters (m) upriver from the Paulins Kill confluence with the mainstem Delaware. The Paulins Kill, along with the mainstem Delaware River and several other nearby tributaries, is known to support the federally endangered Alasmidonta heterodon (dwarf wedgemussel; Galbraith and others, 2016) as well as the New Jersey State 
threatened species Alasmidonta undulata (triangle floater), Lampsilis cariosa (yellow lampmussel), and Lampsilis radiata (eastern lampmussel; Davenport, 2012 ). Upriver from the Columbia Dam, A. heterodon populations may contribute a potentially critical population to the species' range-wide distribution and status (Galbraith and others, 2016). However, few comprehensive and rigorous surveys of freshwater mussels have been conducted in the Paulins Kill impoundments.

The Nature Conservancy (TNC) in New Jersey, in partnership with American Rivers and the New Jersey Department of Environmental Protection, plans to remove the Columbia Dam with the goals of (1) restoring migratory and other native riverine fishes, (2) improving water quality, (3) increasing the abundance of macroinvertebrates and freshwater mussels, and (4) increasing recreational fishing and boating. Preliminary surveys are needed to document existing freshwater mussel populations in the areas of the impoundment to serve as a baseline for evaluating restoration success following dam removal. This preliminary survey was conducted by the U.S. Geological Survey (USGS) and the Delaware Riverkeeper Network in cooperation with TNC. Similar work will be completed for other organisms of interest (American shad, sea lamprey, American eel, and macroinvertebrates) in the basin by researchers at other agencies.

This report presents the results of the semi-quantitative survey of seven species of freshwater mussel in sections of the Paulins Kill, N.J., upriver and downriver from the Columbia Dam during August 2017 (fig. 1). The mussel species richness, number of individuals found, and catch per unit effort (CPUE; number of individual mussels found per person hour of survey time) are presented along with results of a corresponding habitat assessment for each surveyed section of river. Results of this study are compared to results from a 2007 study of number and CPUE of mussels in an upstream part of the Paulins Kill.

\section{Survey Methods}

Semi-quantitative mussel surveys were completed in the vicinity of the Columbia Dam, N.J., during August 22-29, 2017, following methods used by Galbraith and others (2016) to document $A$. heterodon populations throughout the Delaware River Basin. Four or five surveyors continuously snorkeled or SCUBA dove to semi-quantitatively survey for freshwater mussels from the Brugler Road Bridge downriver approximately 2,000 meters to the Columbia Dam and about 300 meters downriver from the dam to 75 meters upriver from the confluence of the Paulins Kill with the Delaware River (fig. 1). Surveyors, who were spread across the river, searched in an upriver direction for mussels in approximately straight-line transects parallel to river flow to cover a section of river (average length $=175 \mathrm{~m}$ ) for 15-20 minutes (average $=19$ minutes). Total river width varied from approximately $30 \mathrm{~m}$ to greater than $200 \mathrm{~m}$; however, owing to dense bankside vegetation, surveyed river width was generally less than $30 \mathrm{~m}$. The substrate was variable, ranging from deep silt close to the Columbia Dam to a mix of cobble, sand, and gravel in other sections. As surveyors encountered mussels, the mussels were briefly removed from the sediment, identified to species, and immediately replaced in their original collection locations. Habitat data were collected for each section of river, as requested by the State of New Jersey, using the Pennsylvania Department of Environmental Protection (PADEP) Habitat Assessment Form 3800-FM-WSFR0117 (PADEP, 2007) protocol as part of a larger initiative to develop predictive metrics of mussel habitat for the State of New Jersey. This protocol is a general bioassessment that evaluates stream and river segments on a scale from 0 to 20 for each of nine habitat parameters; parameter scores from 0 to 5 indicate "poor habitat," from 6 to 10 indicate "marginal habitat," from 11 to 15 indicate "suboptimal habitat," and from 16 to 20 indicate "optimal habitat." Sections were scored on the basis of the following parameters: 1, epifaunal substrate/available cover; 2, pool substrate characterization; 3 , pool variability; 4, sediment deposition; 5, channel flow status; 6 , channel alteration; 7, bank stability (scored for each bank separately); 8 , vegetative protection (scored for each bank separately); and 9 , riparian vegetative zone width (scored for each bank separately).

This methodology was employed for approximately 2,500 $\mathrm{m}$ upriver from the dam (including side channels) and about $300 \mathrm{~m}$ downriver from the dam. Ten sections, including those downriver from the dam, the uppermost approximately $500 \mathrm{~m}$ of the survey region, and side channels, were less than $1.5 \mathrm{~m}$ deep and were surveyed by snorkeling. The remaining deeper six sections were surveyed by SCUBA diving. The approximately $75-\mathrm{m}$ region upriver from the confluence of the Paulins Kill and the Delaware River could not be surveyed because of rapid-like conditions. Additional snorkel surveys were conducted at the river margins (areas bordering the banks and islands), which were covered with dense, submerged and emergent aquatic vegetation. These areas could not be surveyed using the semi-quantitative approach described above. Instead, a modified methodology was employed whereby two surveyors using snorkels surveyed transects perpendicular to flow every $50 \mathrm{~m}$ on both sides of the bank for a total of 2.5 minutes per person ( 5 minutes total survey time per transect per river bank side) within each section, resulting in a total of 20 minutes spent surveying vegetation per approximately $200-\mathrm{m}$ section.

A CPUE value was calculated for each surveyed section of the river. We compared mussel species richness and CPUE upriver and downriver from the dam using a Kruskal-Wallis test owing to violations of the assumptions of analysis of variance (ANOVA). Total habitat scores upriver and downriver from the dam were compared using ANOVA; however, Kruskal-Wallis was used to compare each individual parameter upriver and downriver from the dam. SPSS Statistics software version 20 was used for all statistical analyses. 


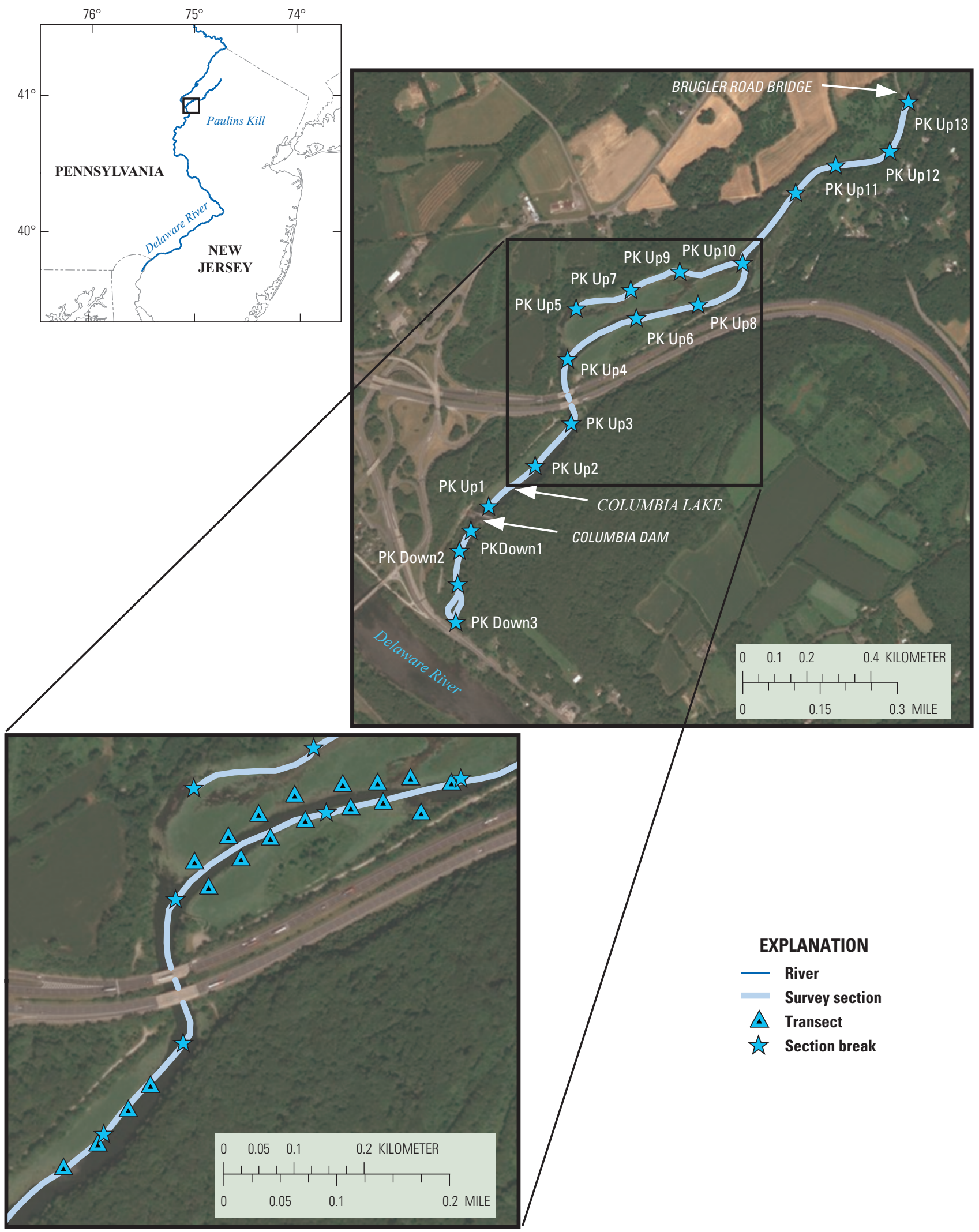

Map images are the intellectual property of Esri and are used herein under license Copyright () 2018 Esri and its licensors. All rights reserved.

Figure 1. Survey sections upriver and downriver from the Columbia Dam in the Paulins Kill, New Jersey. 
Freshwater Mussel Survey for the Columbia Dam Removal, Paulins Kill, New Jersey

\section{Survey Results}

A total of 43 individuals of 2 species, including 42 Elliptio complanata (eastern elliptio) and 1 Pyganodon cataracta (eastern floater), were found within about 2,500 m upriver from the dam in 13 survey sections; no mussels were found within the dense vegetation (table 1). In contrast, 147 individual mussels of 7 species including 106 E. complanta, 27 Utterbackiana implicata, 1 A. undulata, 2 L. cariosa, 6 L. radiata, 4 P. cataracta, and 1 Strophitus undulatus (creeper) were found within about $300 \mathrm{~m}$ downriver from the dam within three survey sections (table 1). Significantly higher species richness $(\mathrm{H}=7.761, \mathrm{p}=0.005)$ and total mussel CPUE $(\mathrm{H}=7.091, \mathrm{p}=0.008)$ were observed downriver from the dam compared to upriver (fig. 2; table 1). However, total habitat score $\left(\mathrm{F}_{(1,14)}=0.027, \mathrm{p}=0.871\right)$ and individual habitat metrics did not differ upriver and downriver from the dam $(\mathrm{H}$ range for individual tests: 3.628 to 0.005 ; p-value range for individual tests: 0.057 for parameter 5 , channel flow status, to 0.945 for parameter 3, pool variability; fig. 3).

\section{Conclusions and Limitations}

Results of the study conducted by the U.S. Geological Survey and the Delaware Riverkeeper Network, in cooperation with The Nature Conservancy, indicate that the region of the Paulins Kill downriver from the Columbia Dam in New Jersey supports a substantial and diverse freshwater mussel fauna, whereas the approximately 2,500-m surveyed region upriver does not. The mussel fauna downriver from the dam included the common species E. complanata and P. cataracta, both found upriver from the dam; five other species were found downriver from the dam but not found in the surveyed sections upriver from the dam. Semi-quantitative surveys of 241 sections of the Paulins Kill upriver from Brugler Road Bridge completed in 2007 documented six of the species observed in this study (table 2), excluding L. cariosa. In fact, the average number of individuals and average CPUE for several species (U. implicata, L. cariosa, L. radiata, and P. cataracta) were higher downriver from the Columbia Dam than those documented in 2007 surveys (table 2), whereas higher numbers of other species (A. heterodon, A. undulata, E. complanata, and S. undulatus) were found further upriver in the 2007 surveys. However, these previously surveyed sections also supported the federally endangered $A$. heterodon, a species not found in the present study.

Total habitat assessment scores were similar in sections upriver and downriver from the dam. Sections downriver from the dam had slightly higher average habitat scores for parameters 1 (epifaunal substrate), 2 (pool substrate), 4 (sediment deposition), and 7 (bank stability); however, none of these differences were significant, probably owing to the low number of survey sections downriver from the dam relative to the number upriver. Survey sections immediately upriver from the dam were dominated by silt, which gradually decreased moving upriver from the impounded reach. The dominant substrate downriver from the dam was a mixture of cobble and sand. Greater vegetation was observed in sections upriver from the dam, creating a dense matrix of plant material below the water's surface. No mussels were found within this plant matrix. The invasive Corbicula fluminea (Asian clam) was found upriver and downriver from the dam but was found in extremely high densities in sections downriver from the dam: living and dead $C$. fluminea created a layer of material on much of the substrate in the lower sections.

Other studies have documented patterns of high freshwater mussel diversity and abundance as well as temporal persistence of mussel populations below lowhead dams (Gangloff and others, 2011; Gangloff, 2013). Small impoundments of less than $7.5 \mathrm{~m}$ have been hypothesized to have positive effects on freshwater mussel communities for a variety of reasons. Mussels downstream from lowhead dams may benefit from increased oxygenation from spillways, stabilized streambeds critical to mussels and host fish, and improved water quality from dams filtering and detoxifying anthropogenically elevated nutrient loads (Gangloff, 2013). Impoundments along streams and rivers can modify temperature and restructure the suspended food regime, perhaps with benefits to filterfeeding organisms, including freshwater mussels (Singer and Gangloff, 2011). Dam removal can therefore be an ecological conundrum, viewed as having negative as well as positive ecological effects, depending on the faunal group of interest. Dam removal restores instream connectivity by opening up miles of previously inaccessible habitat for migratory fish and other species; however, dam removal has also been shown to have negative effects on freshwater mussel communities as far downstream as $2 \mathrm{~km}$ (Sethi and others, 2004; Doyle and others, 2005).

The greatest negative effects of dam removal on mussels have been observed with rapid removal or uncontrolled breaches where mussels in the impounded stretch of river are rapidly dewatered and those downstream are smothered in a plume of sediment (Sethi and others, 2004; Gangloff, 2013). Recent controlled removals, however, have been shown to minimize these effects with some evidence that seasonal timing (removing dams during fall/winter rather than spring/ summer) can reduce stress on affected organisms (Heise and others, 2013). Restoration of mussel populations after dam removal will depend on upstream and downstream propagule sources and the time needed to achieve streambed stabilization (Doyle and others, 2005; Gangloff, 2013). Most of the species found in the present survey have been previously identified farther upriver in the Paulin's Kill during the 2007 surveys (table 2) as well as within the mainstem Delaware River (Blakeslee and others, 2018; St. John White and others, 2018). These populations could aid in the reestablishment of mussels in the vicinity of the Columbia Dam following removal, providing habitat conditions are suitable for juvenile development. 

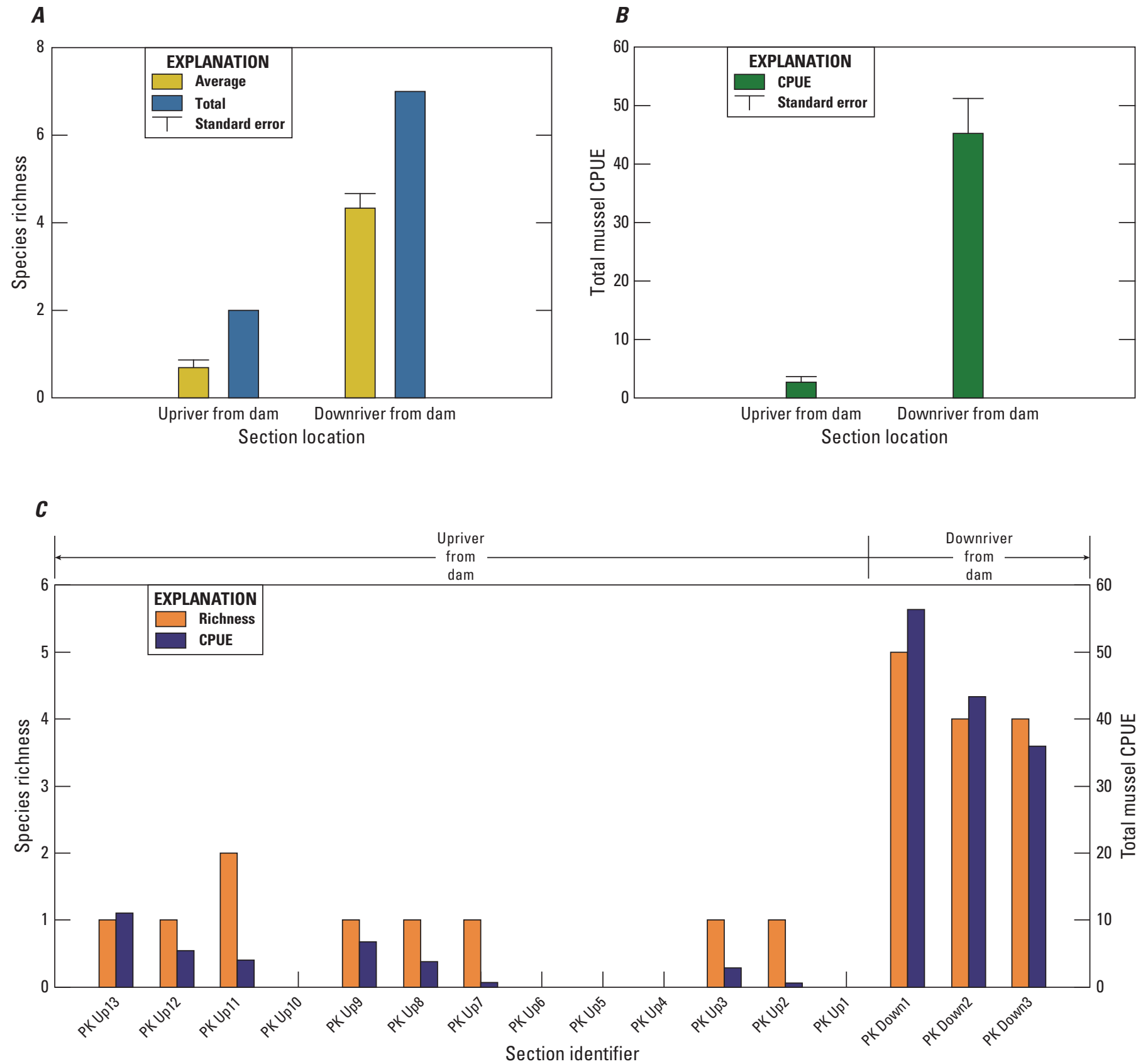

Figure 2. Results of semi-quantitative freshwater mussel surveys in the Paulins Kill, upriver and downriver from the Columbia Dam, New Jersey, August 2017, for $A$, average and total mussel species richness, $B$, total mussel CPUE (catch per unit effort), and $C$, mussel species richness and total mussel CPUE within 16 individual survey sections. (Section identifiers are ordered from upriver [left] to downriver [right]. Species richness is the number of species collected during surveys. CPUE represents the number of individual mussels found per person hour of survey time; Up, upriver; Down, downriver) 


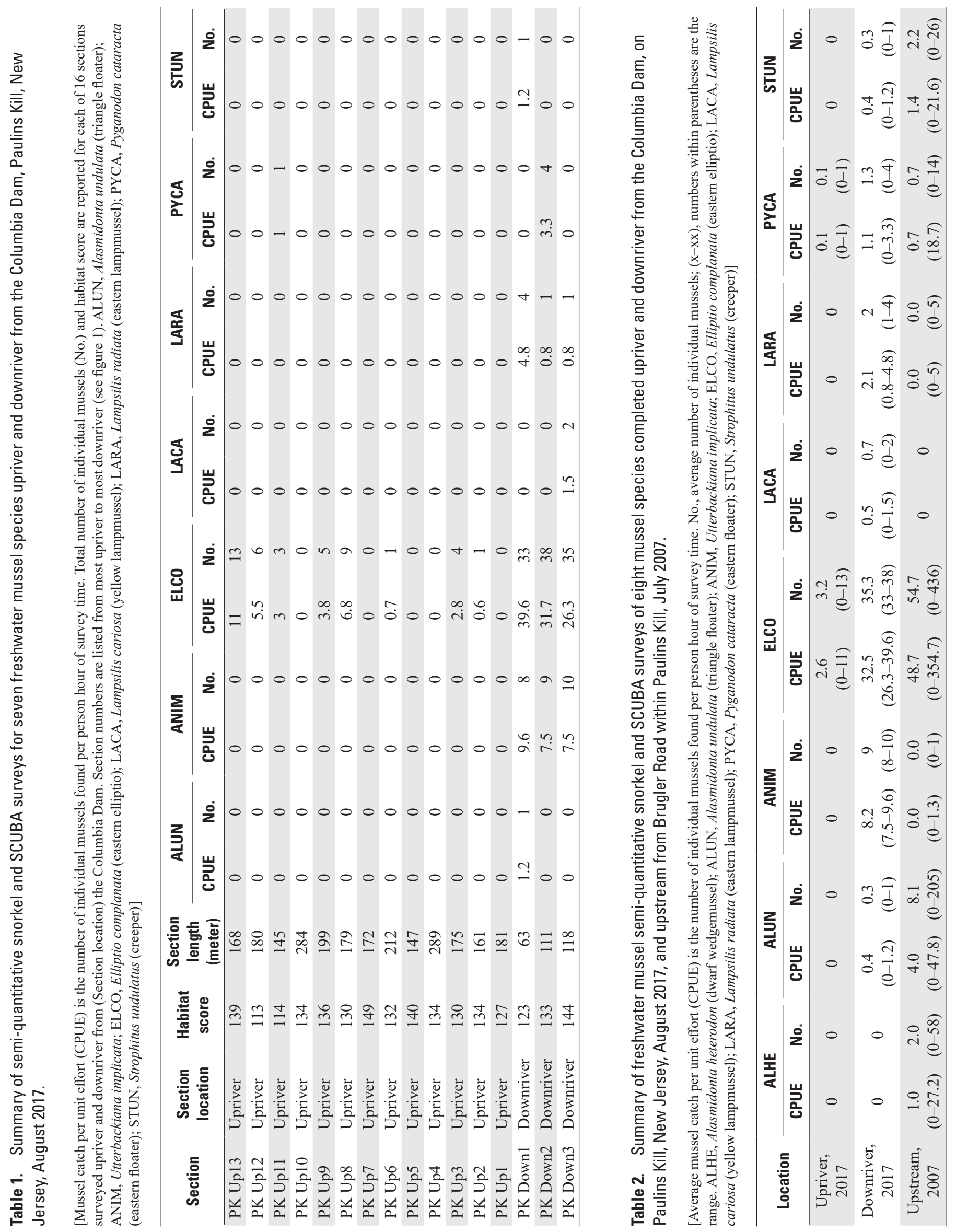




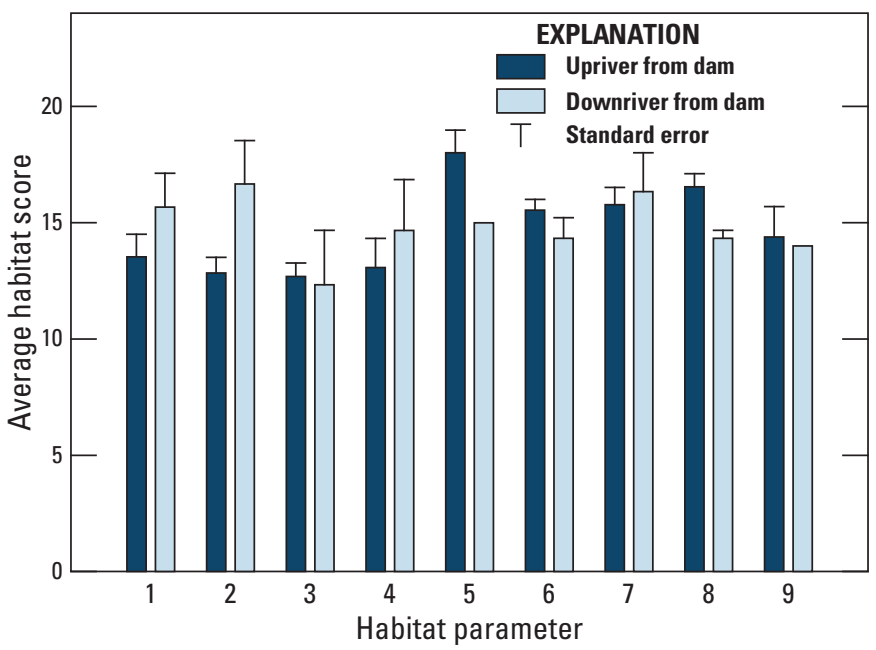

Figure 3. Average (standard error) habitat scores for nine parameters from assessments conducted in the Paulins Kill, New Jersey, upriver and downriver from the Columbia Dam, August 2017. Scores were calculated using the Pennsylvania Department of Environmental Protection Habitat Assessment Form 3800-FM-WSFR0117 (PADEP, 2007). (Parameters 1, epifaunal substrate/available cover; 2 , pool substrate; 3 , pool variability; 4, sediment deposition; 5 , channel flow status; 6 , channel alteration; 7 , bank stability; 8 , vegetative protection; and 9 , riparian vegetative zone width)

\section{References Cited}

Baxter, R.M., 1977, Environmental effects of dams and impoundments: Annual Review of Ecology and Systematics, v. 8, p. 255-283.

Bednarek, A.T., 2001, Undamming rivers: a review of the ecological impacts of dam removal: Environmental Management, v. 27, p. 803-814.

Blakeslee, C.J., Silldorff, E.L., and Galbraith, H.S., 2018, Changes in freshwater mussel communities linked to legacy pollution in the lower Delaware River: Northeastern Naturalist, v. 25, p. 101-116.

Davenport, M.J., 2013, Species status review of freshwater mussels: Trenton, N.J., New Jersey Division of Fish and Wildlife Endangered and Nongame Species Program, 3 p., 3 app.

Doyle, M.W., Stanley, E.H., Orr, C.H., Selle, A.R., Sethi, S.A., and Harbor, J.M., 2005, Stream ecosystem response to small dam removal: Lessons from the Heartland: Geomorphology, v. 71, p. 227-244.

Galbraith, H.S., Lellis, W.A., Cole, J.C., Blakeslee, C.J., and St. John White, B., 2016, Population demographics for the federally endangered dwarf wedgemussel: Journal of Fish and Wildlife Management, v. 7, p. 377-387.
Gangloff, M.M., 2013, Taxonomic and ecological tradeoffs associated with small dam removals: Aquatic Conservation: Marine and Freshwater Ecosystems, v. 23, p. 475-480.

Gangloff, M.M., Hartfield, E.E., Werneke, D.C., and Feminella, J.W., 2011, Associations between small dams and mollusk assemblages in Alabama streams: Journal of the North American Benthological Society, v. 30, p. 1107-1116.

Haag, W.R., 2012, North American freshwater mussels: Natural history, ecology, and conservation: Cambridge, N.Y., Cambridge University Press, 538 p.

Hart, D.D., Johnson, T.E., Bushaw-Newton, K.L., Horwitz, R.J., Bednarek, A.T., Charles, D.F., Kreeger, D.A., and Velinsky, D.J., 2002, Dam removal: challenges and opportunities for ecological research and river restoration: BioScience, v. 52, p. 669-681.

Heise, R.J., Cope, W.G., Kwak, T.J., and Eads, C.B., 2013, Short-term effects of small dam removal on freshwater mussel assemblages: Walkerana, v. 16, p. 45-51.

Pennsylvania Department of Environmental Protection (PADEP), 2007, Habitat assessment field data sheet-low gradient streams, Form 3800-FM-WSFR0117.

Poff, N.L., Olden, J.D., Merritt, D.M., and Pepin, D.M., 2007, Homogenization of regional river dynamics by dams and global biodiversity implications: Proceedings of the National Academy of Sciences of the United States of America, v. 104, p. 5732-5737.

Sethi, S.A., Selle, A.R., Doyle, M.W., Stanley, E.H., and Kitchel, H.E., 2004, Response of unionid mussels to dam removal in Koshkonong Creek, Wisconsin (USA): Hydrobiologia, v. 525, p. 157-165.

Singer, E.E., and Gangloff, M.M., 2011, Effects of a small dam on freshwater mussel growth in an Alabama (USA) stream: Freshwater Biology, v. 56, p. 1904-1915.

St. John White, B., Lellis, W.A., and Cole, J.C., 2018, Qualitative and quantitative surveys of native freshwater mussels in the upper and middle Delaware River (2000-2002): U.S. Geological Survey data release, accessed April 2, 2018, https://doi.org/10.5066/F7222T0M.

Strayer, D.L., Downing, J.A., Haag, W.R., King, T.L., Layzer, J.B., Newton, T.J., and Nichols, S.J., 2004, Changing perspectives on pearly mussels, North America's most imperiled animals: BioScience, v. 54, p. 429-439.

Vaughn, C.C., 2010, Biodiversity losses and ecosystem function in freshwaters: emerging conclusions and research directions: BioScience, v. 60, p. 25-35. 

For additional information, contact:

Director, Leetown Science Center

U.S. Geological Survey

11649 Leetown Road

Kearneysville, WV 25430

or visit our website at:

https://www.lsc.usgs.gov

Publishing support provided by West Trenton Publishing Service Center 


\section{$\frac{\mathbb{2}}{3}$}

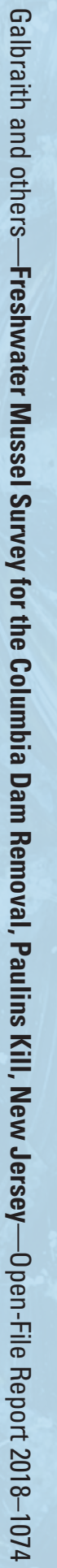

